\title{
PENGARUH DIKLAT PENINGKATAN KOMPETENSI GURU IPA MTS TERHADAP PEMAHAMAN GURU IPA MTS DALAM MEMBUAT RENCANA PELAKSANAAN PEMBELAJARAN (RPP)
}

\author{
Lilis Suryani ${ }^{1}$ \\ ${ }^{1}$ Balai Diklat Keagamaan Palembang \\ ${ }^{1}$ Email; lilisbdk.ms67@gmail.com
}

Diterima: 4 Juli 2021 | Disetujui: 14 Juli 2021 | Dipublikasikan : 16 Juli 2021

\begin{abstract}
Abstrak
Penelitian ini termasuk penelitian institusional karena bertujuan untuk mendapatkan informasi berkaitan pengaruh diklat tertentu yang dapat digunakan untuk pengembangan lembaga Pendidikan dan Latihan dalam hal ini Balai Diklat Keagamaan. Jika dilihat dari analisa datanya termasuk penelitian kuantitatif karena analisis datanya menggunakan uji statistik (Regresi sederhana) Sedang tujuan penelitian ini adalah: a) Untuk mengetahui seberapa baik keikutsertaan guru IPA MTs terhadap diklat guru IPA, b) Untuk mengetahui seberapa baik kinerja guru IPA dalam membuat Rencana Pelaksanaan Pembelajaran (RPP) yang merupakan perangkat yang harus disiapkan guru dalam mengajar, c) Untuk mengetahui ada tidaknya pengaruh diklat guru IPA MTs terhadap kinerja guru dalam membuat RPP. Dari analisa data diperoleh kesimpulan: a) Keikutsertaan guru IPA MTs dalam diklat guru IPA dapat dikatakan mendekati baik, b) Kinerja guru dalam membuat Rencana Pelaksanaan Pembelajaran (RPP) baik, dan c) Ada pengaruh yang signifikan antara keikutsertaan diklat guru IPA MTs terhadap kinerja guru dalam membuat Rencana Pelaksanaan pembelajaran (RPP). Ini berarti keikutsertaan guru dalam setiap materi kediklatan meningkatkan kualitas kinerjanya dalam membuat Rencana Pelaksanaan Pembelajaran (RPP).
\end{abstract}

Kata Kunci : Diklat guru IPA, Kinerja guru IPA

\section{Abstract}

[PENGARUH DIKLAT PENINGKATAN KOMPETENSI GURU IPA MTS TERHADAP PEMAHAMAN GURU IPA MTS DALAM MEMBUAT RENCANA PELAKSANAAN PEMBELAJARAN (RPP)] This research is come under the institutional research because have purpose to gaining information about the influence of certain training which can be use to development of institution. The analysis of data is fall under the quantitatif method using statistics test (simple regression). The purpose of this research are : a) For knowing how well the presence of science state junior high school with training for science school teacher. b) For knowing how well skill of science teacher in arranging lesson plan. c) For knowing is there any influence of Training for Science state Islamic junior high school teacher in arranging lesson plan. The result from data analysis are : a) The presence of science state islamic junior high school is rated as good. b) The performance of teacher in arrange lesson plan is good. c) There is a significant impact between the presence of science state islamic junior high school teacher with teacher's perfomance in arranging lesson plan. In conclusion, the presence of teacher in every training materials have escalate the performance to arrangong lesson plan.

Keyword : Training for science state islamic junior high school, Performance of science teacher

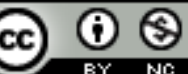

This work is licensed under a Creative Commons Attribution-NonCommercial 4.0 International 


\section{PENDAHULUAN}

Dalam kegiatan Pendidikan dan Latihan (Diklat) proses belajar yang diberikan oleh Widyaiswara diharapkan dapat berlangsung secara tertib,interaktif, inspiratif, dan menyenangkan, untuk memotivasi peserta Pedidikan dan Latihan (Diklat) agar dapat berpartisipasi aktif maka dilakukan secara lengkap dan berurutan atau terstruktur. Diklat yang dilaksanakan oleh Balai Diklat Keagamaan Palembang khususnya merupakan suatu program yang dirancang dan disusun oleh bagian perencana untuk dapat meningkatkan pengetahuan dan juga sebagai upaya untuk mengembangkan kemampuan intelektual dan kepribadian bagi peserta Pendidikan dan Latihan (Diklat). (menurut pendapat admojo.N, tahun 2003).

Pendidikan dan Latihan yang diikuti oleh guru atau tenaga Pendidik ini adalah bertujuan untuk meningkatkan kompetensi atau kemampuan bagi guru dalam melaksanakan tugasnya sebagai tenaga pendidik dan juga untuk mengembangkan keahlian atau kemampuan peserta Pendidikan dan Latihan (Diklat) atau sumber daya manusia (SDM) dalam mengikuti kegiatan Pelatihan yang diberikan oleh para Widyaiswara (nara sumber), Ketika Kembali ketempat tugas semua peserta yang mengikuti pelatihan akan dapat mengembangkan dan meningkatkan kinerja mereka (Tziner at all, tahun 1993). Berdasarkan Regulasi atau Peraturan yang dikeluarkan oleh Mentri Agama yaitu PMA No. 3 tahun 2006 yang kemudian diterjemahkan kedalam kebijakan teknis kepala badan litbang dan diklat kementerian agama

Diklat yang diselenggarakan oleh Balai Diklat Keagamaan Palembang bertujuan untuk meningkatkan kompetensi teknis bagi Aparatur Sipil Negara (ASN) yang bertugas sebagai pegawai tenaga teknis keagamaan di lingkungan Kementerian Agama dan atau para pegawai non ASN yang bekerja sebagai karyawan di Kementerian Agama berdasarkan kebutuhan riil sebagai diskrepansi (gap competency). Setiap pelaksanaan diklat perlu dilakukan evaluasi sehingga mendapatkan gambaran tentang peningkatan kemampuan individu pegawai, dampak diklat bagi peningkatan kualitas bagi instansi dalam memecahkan masalah penyelesaian tugas kualitas kerja dan tujuan instansi (Hastari, 2013)

Dalam Undang Undang Dasar Negara Ripublik Indonesia (UU No. 20 tahun 2003) Menetapkan bahwa pendidikan Nasional merupakan suatu upaya mencerdaskan kehidupan bangsa Indonesia dan meningkatkan kualitas martabat bangsa Indonesia membentuk suatu kepribadian yang terpuji dan meningkatkan nilai-nilai keimanan dan ketaqwaan kepada Tuhan Yang Maha Esa serta menguasai ilmu pengetahuan tekhnologi (IPTEK) dan seni dalam mewujudkan masyarakat yang maju, adil, sejahtera dan memiliki suatu kepribadian yang terpuji. Suatu tingkat pencapaian yang baik dan sangat ideal dan tentunya membutuhkan suatu usaha yang tinggi dan tidak muda untuk mendapatkannya.

Sebagai sebuah system dalam Pendidikan atau prosesur Pendidikan ada banyak hal dan faktor didalamnya yang berperan untuk meningkatkan mutu Pendidikan salah satu diantaranya adalah guru yang sangat berpengaruh untuk memberi Pendidikan kepada semua peserta didik. Guru merupakan penentu keberhasilan pelaksanaan Pendidikan di suatu tingkat satuan Pendidikan. Regulasi atau Peraturan yang ditetapkan oleh Pemerintah yaitu UU RI No.14 tahun 2005 tentang guru dan dosen pasal 1 mengatakan bahwa guru adalah seorang pendidik professional dan berkomitmen tinggi dengan tugas utama mendidik, mengajar, membimbing, mengarahkan, melatih, menilai dan mengevaluasi peserta didik untuk memahami pengetahuan yang mereka berikan pada Pendidikan anak usia dini jalur Pendidikan formal, Pendidikan tingkat dasar, Pendidikan tingkat menengah dan juga sampai kependidikan tingkat atas. Dengan beban tugas utama yang dimiliki oleh guru dan ditetapkan dalam Undang-Undang, begitu banyak dan komplek beban tugas utama yang diberikan kepada guru tentunya sangat 
diperlukan pengetahuan dan kemampuan yang tinggi agar tugas yang dibebankan tersebut dapat dilaksanakan dengan sebaikbaiknya (Darsana W., tahun 2012).

Rendahnya mutu dan kemerosotan Pendidikan yang tengah dihadapi dan merupakan ancaman di Indonesia sudah kita rasakan selama bertahun tahun, Pemrintah Indonesia selalu mengevaluasi dan merevisi kurikulum dalam meningkatkan mutu Pendidikan di Indonesia sampai sekarang Pemerintah terus mengevaluasi. Kurikulum atau pedoman guru dalam mengajar sudah beberapa kali mengalami perubahan. Perubahan kurikulum pertama kali adalah kurikulum 1975 diganti dengan kurikulum 1984, kemudian kurikulum 1984 diganti lagi dengan kurikulum 1994, dalam perubahan kurikulum atau pedoman guru dalam mengajar yang dilakukan oleh pemerintah ini membuat banyak guru-guru atau tenaga pendidik yang belum siap menerima perubahan kurikulum yang dilakukan oleh Pemerintah.

Hal ini tercermin dengan adanya upaya Pemerintah mengubah kurikulum ini mulai kurikulum 1975 diganti dengan kurikulum 1984 saat itu dipakai sebagai pedoman guru dalam mengajar kemudian oleh Pemerintah kurikulum tersebut dievaluasi dan ternyata masih banyak kekurangan-kekurangan dari kurikulum tersebut, maka Pemerintah merevisi Kembali kurikulum 1984, dan diganti dengan kurikulum 1994, dengan tujuan untuk memperbaiki dari kekurangankekurangan isi dari pada kurikulum 1984 agar sistem Pendidikan di Indonesia menjadi lebih baik Nasanius (1998). Mengungkapkan Pendidikan di Indonesia sekarang ini sangat memprihatinkan sekali hal ini terbukti dengan rendahnya mutu atau kemerosotan Pendidikan di Indonesia. Kemerosotan Pendidikan ini bukan diakibatkan oleh adanya perubahan kurikulum tetapi disebabkan kurangnya tingkat kemampuan profesionalisme guru dalam menyampaikan materi kepada peserta didik di masing masing Satuan Pendidikan di Indonesia.

Untuk kelancaran guru atau tenaga pendidik dalam melaksanakan tugasnya sebagai tenaga pengajar dan juga untuk meningkatkan profesionalisme guru dalam mengajar sangat diperlukan sekali bakat dan minat yang dimiliki oleh guru atau tenaga pendidik sejak pertama sekali duduk di bangku sekolah dan bukan merupakan suatu paksaan dari orang tua atau pihak manapun juga. Dua faktor besar yang dapat dilihat pertama adalah faktor internal yang meliputi minat dan bakat yang sudah dimiliki sejak duduk di bangku sekolah. Kemudian yang ke dua faktor eksternal berkaitan dengan pemanfaatan lingkungan sekitar madrasah untuk dijadikan sebagai media sumber belajar bagi anak-anak didik, artinya guru-guru dituntut untuk menjadi guru yang dapat membuat anak-anak didik termotivasi dalam belajar dengan menggunakan media pembelajaran ini akan membuat peserta didik tidak jenuh dalam belajar dengan menggunakan lingkungan sebagai media pembelajaran akan membuat anak anak dan menanamkan kepada anak-anak untuk mencintai lingkungan, dan juga dengan sarana prasarana yang lengkap artinya semua yang dibutuhkan oleh peserta didik dalam proses pembelajaran terpenuhi terutama media pembelajaran.

Madrasah yang mempunyai sarana dan prasarana yang memenuhi standar akan membuat proses belajar mengajar di Madrasah tersebut akan berjalan dengan lancer. Untuk menunjang kemampuan dan profesionalisme guru dalam mengajar hendaknya Madrasah dapat memfasilitasi guru dalam pengembangan profesi guru (Sumargi, tahun1966) Profesionalisme guru dan tenaga kependidikan masih belum memenuhi standar yang sudah ditetapkan oleh pemerintah, seperti dalam hal bidang keilmuan atau materi yang diajarkan kepada peserta didik tidak sesuai dengan bidang yang diampuh . Masih banyaknya guru dan tenaga kependidikan yang belum memenuhi standar dan juga masih rendahnya tingkat kompetensi tenaga pendidik dan Kependidikan.

Banyak guru-guru yang mengajar bukan bidang keahlian yang diampuh dan bukan spesialisasi guru-guru tersebut sehingga banyak ditemukan guru yang mengajar asal-asalan. Misalnya guru Iimu 
Pengetahuan Alam ditugaskan untuk mengajar matematika. Ataupun guru Ilmu Pengetahuan Sosial ditugaskan untuk mengajar Bahasa Indonesia jadi banyak guru yang salah kamar dalam mengajar (dalam Purwanto, N. tahun 2000).

Jumlah rekrutmen tenaga pendidik atau guru di Indonesia sudah cukup banyak , tetapi kalau dilihat dari segi mutu dan kualitas ataupun kemampuan dalam mengajar masih rendah jika dibandingkan dengan Negara tetangga kita seperti negara Singapura suatu negara yang dijuluki kepala singa yang merupakan negara ekonomi terbaik di dunia, baik Pendidikan maupun pelatihan, dalam Pendidikan negara ini memiliki tenaga pengajar dan Sumber Daya Manusia (SDM) yang berkualitas dan dapat diandalkan. Sedangkana di Indonesia banyak guruguru yang kurang mampu dalam memilih materi-materi yang asensial, otomatis guru-guru tersebut tidak menarik dalam mengajar karena kurangnya kemampuan guru-guru dalam menyampaikan materi pelajaran kepada peserta didik yang tidak sesuai denga apa yang sudah ditetapkan dalam kurikulum.

Dengan kurang mampunya tenaga tenaga pendidik dalam menyajikan materi, ini mengakibatkan tidak tercapainya penyelenggaraan Pendidikan yang benarbenar berkualitas (dalam Dahrin, tahun 2000). Disisi lain, sering dijumpai adanya guru yang kurang mampu menjalankan tugas yang menjadi tanggung jawabnya dengan baik. Kekurang mampuan guru dalam menjalankan tugasnya disebabkan karena ketidaktahuan mereka terhadap prosedur kerja yang seharusnya mereka lakukan (Danim, Sudarwan, 2002).

Disamping itu tidak adanya fasilitas internet untuk mengakses informasiinformasi seperti untuk mengetahui perubahan kebijakan atau adanya regulasi yang terbaru yang di tetapkan oleh pengambil keputusan atau kebijakan, apalagi bagi mereka yang mengajar di tempat terpencil yang jauh dari pusat keramaian. Sehingga, banyak tenaga pendidik atau guru sering terlambat untuk mengetahui segala bentuk informasi salah satunya informasi tentang dunia
Pendidikan, misalnya tentang perubahanperubahan aturan-atauran kependidikan yang selalu direvisi dan di evaluasi oleh pemangkuh kebijakan atau Pemerintah.

Di sinilah, Balai Diklat khususnya Balai Diklat Keagamaan Palembang sebagai kepanjangan tangan dari Kementerian Agama memiliki fungsi yang strategis dalam memberdayakan para guru tersebut melalui serangkaian kegiatan pendidikan dan pelatihan yang dilaksanakan ( dalam Danim, Sudarwan, tahun 2002).

Setiap pelaksanaan kegiatan Pendidikan dan Latihan (Diklat) apabila telah selesai dilaksanakan selalu dilakukan monitoring dan Evaluasi (Monev) dalam rangka menentukan seberapa besar tingkat keberhasilan dan ketercapaian proses Pendidikan dan Latihan (Diklat) yang diberikan, tidak terkecuali proses pendidikan dan pelatihan yang dilaksanakan di Balai Pendidikan dan Pelatihan Keagamaan Palembang, Supriyono (tahun 2007) Evaluasi yang dimaksud tidak hanya mencakup out put akan tetapi juga out comenya. Hal tersebut sejalan kebijakan yang ditetapkan oleh Pemerintah tentang kebijakan dalam pemantauan dan pemberdayaan alumni disebutkan bahwa perlu adanya evaluasi pasca Pendidikan dan Latihan (diklat).

Para alumni Pendidikan dan Latihan selalu di evaluasi untuk melihat perubahan atau melihat bagaimana para alumni Diklat itu dalam mengimplimentasikan ilmu yang mereka dapati selama mengikuti proses Pendidikan dan Latihan (Diklat), Minimal mereka melakukan perubahan terhadap dirinya sendiri setelah mereka kembali ke lingkungan kerja masing-masing, karena proses pembelajaran yang baik memerlukan perencanaan yang baik melalui penyusunan perangkat pembelajaran yaitu Rencana Pelaksanaan Pembelajaran, berdasarkan Peraturan Mentri Pendidikan dan Kebudayaan Nomor 22 tahun 2016 yang mengatur tentang Standar Nasional Pendidikan (SNP) salah satunya Standar Proses, Pendidikan tingkat Dasar dan Pendidikan tingkat Menengah dinyatakan dalam Standar Proses yang merupakan suatu 
kriteria mengenai pelaksanaan dalam proses belajar mengajar atau proses pembelajaran pada Satuan Pendidikan (Sekolah) tingkat dasar dan satuan pendidikan tingkat menengah untuk memenuhi kriteria dan mencapai kompetensi lulusan yang terbaik, berkualitas dan dapat disejajarkan dengan tingkat Internasional dan bisa diakui dunia.

Pemerintah selalu berusaha untuk meningkatkan mutu dan kualitas pendidikan di Indonesia melalui berbagai macam program dan usaha yang telah, sedang dan akan dilaksanakan. Salah satu upaya nyata yang dilaksanakan Pemerintah adalah melalui perbaikan kualitas pendidikan dalam hal ini adalah tenaga pendidik (guru). Untuk menjamin kepastian hukum profesi guru, maka Pemerintah telah mensahkan UndangUndang Nomor 14 tahun 2005 yang mengatur tentang Guru dan Dosen. Tugas utama seorang guru yang sudah tertuang dalam Undang-Undang adalah mendidik, mengajar, melatih, menilai dan mengevaluasi peserta didik (Muhammad Saroni, 2011).

Untuk dapat melaksanakan dan menjalani tugas sebagai tenaga pendidik, maka seorang guru dituntut untuk menjadi seorang guru yang benar-benar memiliki tingkat kompetensi dan kemampuan yang tinggi untuk menjadikan diri lebih professional dalam hal mengajar kepada peserta didik di satuan Pendidikan atau sekolah dimana guru tersebut ditugaskan untuk mengajar. Sebagaimana diungkapkan dan tertera dalam pasal 7 Undang Undang Guru dan Dosen bahwa profesi dan tugas guru itu merupakan suatu bidang pekerjaan atau tugas yang diberikan kepada guru yang benar-benar harus dilaksanakan oleh guru sebagai tenaga pengajar, berdasarkan prinsip prinsip tertentu sesuai denga apa yang sudah ditetapkan dalam Undang Undang yang mengatur tentang tugas dan profesi guru atau tenaga pendidik. Dua diantara prinsip tersebut adalah salah satunya guru harus memiliki kualifikasi akademik berstrata minimal S1 dan latar belakang pendidikan yang sesuai dengan disiplin ilmu dalam pelaksanaan bidang tugas dan yang kedua dan harus digaris bawahi adalah guru harus memiliki kompetensi yang diperlukan sesuai dengan bidang tugasnya (Kemendiknas. (tahun 2007).

Selanjutnya kompetensi yang dimaksud diatas harus dimiliki oleh guru adalah kompetensi pedagogik, Kepribadian, Sosial dan Profesional.

Pembahasan selanjutnya akan difokuskan pada kompetensi pedagogik dengan alasan sejalan dengan alur pemikiran dalam penulisan penelitian ini (Barinto 2012). Ada empat kompetensi yang dimiliki oleh guru salah satunga adalah kompetensi pedagogik, kompetensi ini merupakan kemampuan atau keterampilan guru yang dapat mengelolah suatu proses pembelajaran atau guru dapat berinteraksi dalam proses belajar mengajar Bersama peserta didik yang sekurang kurangnya meliputi: Pemahaman wawasan landasan kependidikan, Pemahaman terhadap peserta didik, pengembangan kurikulum, perancangan pembelajaran, pelaksanaan pembelajaran yang mendidik dan diologis, pemanfaatan tekhnologi pembelajaran, Evaluasi hasil belajar dan pengembangan peserta didik untuk mengaktualisasikan berbagai potensi yang dimilikinya Peraturan Pemerintan yang mengatur tentang Guru; tahun 2007.

Mengingat begitu penting dan luasnya kompetensi pedagogik yang harus dimiliki oleh guru, maka peneliti hanya memfokuskan pada lima unsur sesuai dengan format Alat Penilai Kemampuan Guru (APKG1) yaitu perumusan tujuan pembelajaran, pemilihan dan pengorganisasian materi dalam proses belajar mengajar seperti bahan ajar, dalam bahan ajar atau metri yang akan diberikan harus disertai dengan sumber pembelajarannya, pemilihan sumber belajar atau media pembelajaran harus disesuaikan dengan materi yang akan diajarkan, skenarioatau kegiatan pembelajaran dan penilaian hasil belajar siswa yang dilakukan oleh guru semuanya harus dicantumkan dalam Rencana Pelaksanaan Pembelajaran (RPP).

Penyusunan Rencana Pelaksanaan Pembelajaran (RPP) yang baik akan sangat mempengaruhi terhadap perilaku 
pembelajaran yang dilakukan oleh guru atau tenaga pendidik.

Sebagai seorang guru atau tenaga pendidik harus memiliki kemampuan atau kompetensi dalam membuat atau menyusun perencanaan pembelajaran (RPP) dan bagaimana seorang guru dalam melaksanakan proses pembelajaran di kelas, karena ini merupakan bagian dari kompetensi pedagogik guru yang harus dimiliki oleh guru untuk bisa melakukan dan melaksanakan tugasnya dalam proses pembelajaran yang mendidik sebagai persyaratan guru profesional (Permendiknas no. 41 tahun 2007).

Perencanaan program pembelajaran merupakan suatu sistem pengajaran yang sudah ditetapkan dalam kurikulum yang berfungsi untuk memberikan suatu arahan pelaksanaan pembelajaran sehingga proses pembelajaran menjadi terarah, efisien dan tidak melebar kemana-mana bagi guru terutama dalam mengatur alokasi waktu pada Rencana Pelaksanaan Pembelajaran yang akan digunakan guru untuk melaksanakan proses belajar mengajar di kelas. Kegiatan dalam melaksanakan perencanaan pembelajaran diantaranya meliputi memperkirakan tuntutan dan kebutuhan, menentukan tujuan, menulis kegiatan pembelajaran, menentukan topik topik yang akan diberikan pada proses pembelajaran dan mengalokasikan waktu pada setiap mata pelajaran yang akan diberikan waktu proses belajar mengajar (PBM), serta menentukan sumber sumber yang diperlukan (Rohani dan Ahmadi, tahun 1990).

Salah satu bagian dari perencanaan pembelajaran yang sangat penting dibuat oleh guru sebagai pengarah pembelajaran adalah penyusunan Rencana Pelaksanaan Pembelajaran yang merupakan salah satu perangkat pembelajaran yang harus di siapkan oleh guru dalam mengajar. Rencana Pelaksanaan Pembelajaran dijabarkan dari silabus untuk mengarahkan kegiatan belajar mengajar peserta didik untuk mencapai kompetensi dasar. Selain itu RPP juga memuat tekhnik penilaian seperti apa untuk menguji sejauh mana keberhasilan pembelajaran Permendiknas no. 18 tahun 2007.
Rencana Pelaksanaan Pembelajaran adalah merupakan alat atau instrumen untuk mengukur suatu perencanaan dalam pembelajaran yang lebih spesik atau lebih khusus dari silabus, Rencana Pelaksanaan Pembelajaran ini sudah ditetapkan dalam Peratutan Mentri Pendidikan dan Kebudayaaan nomor 81A tahun 2013 yaitu tentang implimentasi kurikulum, dimana seluruh tenaga Pendidik atau guru harus melaksanakan kurikulum yang telah ditetapkan oleh Pemerintah, gur wajib membuat perangkat pembelajaran dalam mengajar salah satunya Rencana Pelaksanaan Pembelajaran (RPP) Manfaata dari penyusunan atau membuat RPP ini bagi guru adalah sebagai panduan atau pedoman bagi guru dalam mengajar agar tidak melebar jauh dari tujuan pembelajaran.

Rencana Pelaksanaan Pembelajaran (RPP) dapat dibuat untuk setiap satu kali pertemuan dan juga dapat dibuat untuk persemester dalam pelaksanaan atau proses pembelajaran yang akan dilaksanakan oleh guru, seluruh tenaga pendidik diharuskan dalam membuat Rencana Pelaksanaan Pembelajaran tanpa adanya RPP maka proses pembelajaran akan ngambang dan tidak terarah.

Dari hal tersebut, maka perlu dilakukan suatu penelitian tentang "Pengaruh Diklat Guru IPA Tingkat MTs terhadap Pemahaman dalam membuat Rencana pelaksanaan pembelajaran".

\section{RUMUSAN MASALAH}

Permasalahan yang akan diangkat dalam penelitian ini adalah:

1. Seberapa baik keikutsertaan guru IPA MTs terhadap diklat guru IPA?

2. Seberapa baik kualitas RPP yang dibuat oleh guru IPA MTs?

3. Apakah ada pengaruh Pendidikan dan Latihan (diklat) untuk meningkatkan Kompetensi guru IPA Tingkat MTs terhadap kinerja guru dalam membuat Rencana Pelaksanaan Pembelajaran (RPP)? 


\section{TUJUAN PENELITIAN}

Tujuan dari penelitian yang dilaksanakan oleh peneliti dalam hal ini adalah :

1. Untuk mengetahui seberapa baik keikutsertaan guru IPA MTs terhadap diklat guru IPA

2. Untuk mengetahui seberapa baik kinerja guru IPA dalam membuat RPP

3. Untuk mengetahui ada tidaknya pengaruh diklat guru IPA MTs terhadap kinerja guru dalam membuat RPP.

\section{MANFAAT PENELITIAN}

Setelah dilihat dari pokok permasalahan maka Penelitian ini sangat penting dan bermanfaat sekali bagi peneliti karena:

1. Memperoleh gambaran tentang ada tidaknya pengaruh diklat guru IPA terhdap kinerja guru IPA dalam membuat Rencana Pelaksanaan Pembelajaran di sekolah.

2. Mendapatkan gambaran tentang diklat-diklat yang akan datang.

\section{VARIABEL}

1. Diklat guru IPA MTs mengandung beberapa indikator antara lain:

a. Seberapa aktip keikiutsertaan guru dalam diklat IPA .

b. Seberapa penting materi diklat IPA yang diberikan oleh widyaiswara.

c. Seberapa jauh pengamalan materi diklat guru IPA sekembali di sekolah.

d. Seberapa pengembangan materi diklat IPA sekembali di sekolah.

2. Kinerja guru adalah bagaimana kinerja guru dalam membuat RPP dan seberapa kualitas RPP sains MTs yang dibuat oleh alumni peserta diklat guru IPA. Sedang yang dimaksud kualitas RPP adalah seberapa kesesuaian dan kerevansian RPP baik dari sisi konstruksi maupun prinsip- prinsip pembuatan RPP sesuai Permendiknas RI Nomor 41 Tahun 2007

\section{METODE PENELITIAN}

Dilihat dari bidangnya, penelitian ini termasuk penelitian institusional karena bertujuan untuk mendapatkan informasi dan juga merupakan suatu penelitian untuk memahami masalah-masalah yang terdapat pada instansi atau lembaga, dapat digunakan untuk mengembangkan lembaga atau Instansi menjadi lebih baik dalam meningkatkan mutu dan kinerja semua karyawan yang ada pada instansi atau lembaga yang menyelenggarakan Pendidikan dan Latihan (Diklat) itu sendiri dalam hal ini adalah Instansi penyelenggara pelatihan Balai Diklat Keagamaan Palembang. Jika dilihat dari analisa datanya termasuk penelitian kuantitatif karena analisis datanya menggunakan uji statistik (Regresi sederhana)

\section{Populasi Penelitian}

Populasi merupakan totalitas atau jumlah dari keseluruhan atau semua nilai yang mungkin, hasil dari penghitungan, ataupun pengukuran secara keseluruhan, baik dari segi kuantitatif maupun kualitatif mengenai karakteristik dari subyek yang diteliti ataupun dari semua anggota kumpulan yang lengkap dan jelas dipelajari sifat-sifat dari subjek penelitian, sedangkan sampel yaitu bagian yang diambil dari populasi atau bagian-bagian yang mewakili dari populasi untuk di teliti ( sudjana 1996:6).

Dalam penelitian ini peneliti menggunakan teknik random sampling atau teknik yang dilakukan peneliti secara acak atau tidak beraturan, jadi setiap anggota populasi mempunyai kesempatan yang sama untuk dipilih oleh peneliti menjadi anggota sampling dalam penelitian ini ( Hadi ; tahun 1997:75). Tentang seberapa besarnya sampel yang akan diambil oleh peneliti dalam penelitian ini maka penelitia akan mengambil secara acak atau tidak beraturan, bila subyek yang diambil oleh peneliti kurang dari 100 maka subjeknya akan diambil semua, dan jika 
subjek yang diambil oleh peneliti besar maka subjek yang diambil 10\% - 15\%, $20 \%-25 \%$ atau lebih (Arikunto 1989: 07).

Menurut data statistik yang ada pada Balai Pendidikan dan Latihan (Diklat) tenaga Teknis Keagamaan Palembang, jumlah alumni Pendidikan dan Latihan (diklat) guru Ilmu Pengetahuan Alam (IPA) berjumlah 40 orang, yaitu alumni Pendidikan dan Latihan (Diklat) guru Ilmu Pengetahuan Alam (IPA).

\section{Sampel penelitian}

Peneliti mengambil guru-guru alumni Pendidikan dan Latihan (Diklat) guru Ilmu Pengetahuan Alam (IPA) Tingkat Madrasah Tsanawiyah Provinsi Sum Sel, Provinsi Lampung, Bengkulu dan Bangka Belitung tahun 2019 sebagai sempel penelitian. Sedangkan sampel penelitian diambil secara acak / random berjumlah 21 guru alumni Diklat Guru IPA Madrasah Tsanawiyah.

\section{TEMUAN DAN PEMBAHASAN}

\section{Temuan}

A. Instrumen atau alat ukur yang dipakai dalam Penelitian ini.

1) Diklat guru IPA MTs (variabel X)

Untuk mengukur variabel $\mathrm{X}$ digunakan instrumen Diklat Guru Ilmu Pengetahuan Alam (IPA) Tingkat MTs

2) Kinerja guru dalam membuat RPP (variabel Y)

Untuk mengukur variabel $\mathrm{Y}$ digunakan instrumen kinerja guru

\section{B. Teknik Pengumpulan Data}

Untuk memperoleh data-data dari lembar instrumen yang ada digunakan alatalat pengumpul data sebagai berikut:

1) Angket dan Wawancara

Peneliti telah memberikan angket kepada subyek penelitian baik secara langsung maupun lewat surat pos. Pada saat peneliti ke tempat tugas guru peneliti memberikan Tanya-jawab untuk menggali informasi sesuai dengan tujuan penelitian

2) Dokumentasi :

Untuk mengukur kualitas RPP yang dibuat oleh guru maka peneliti mengumpulkan RPP para guru tersebut.

\section{Teknik Analisis Data}

\begin{tabular}{|l|l|l|l|}
\hline No & $\begin{array}{l}\text { Rumusan } \\
\text { Masalah }\end{array}$ & Hipotesis & $\begin{array}{l}\text { Uji } \\
\text { Hipotesi } \\
\text { s }\end{array}$ \\
\hline 1. & $\begin{array}{l}\text { Seberapa } \\
\text { tinggi } \\
\text { keikutsertaan } \\
\text { guru IPA } \\
\text { MTs } \\
\text { terhadap } \\
\text { diklat guru } \\
\text { IPA? }\end{array}$ & $\begin{array}{l}\text { Keikutsertaa } \\
\text { n guru IPA } \\
\text { terhadap } \\
\text { diklat guru } \\
\text { IPA tinggi }\end{array}$ & $\begin{array}{l}\text { Deskripi } \\
\text { satu } \\
\text { variabel }\end{array}$ \\
\hline 2. & $\begin{array}{l}\text { Seberapa } \\
\text { tinggi } \\
\text { kualitas RPP } \\
\text { yang dibuat } \\
\text { oleh guru } \\
\text { IPA MTs? }\end{array}$ & $\begin{array}{l}\text { Kualitas } \\
\text { RPP yang } \\
\text { dibuat oleh } \\
\text { guru IPA } \\
\text { MTs baik }\end{array}$ & $\begin{array}{l}\text { Deskripi } \\
\text { satu } \\
\text { variable }\end{array}$ \\
\hline 3. & $\begin{array}{l}\text { Bagaimanaka } \\
\text { h pengaruh } \\
\text { diklat guru } \\
\text { IPA MTs } \\
\text { terhadap } \\
\text { kinerja guru } \\
\text { dalam } \\
\text { membuat } \\
\text { RPP? }\end{array}$ & $\begin{array}{l}\text { Diklat guru } \\
\text { IPA MTs } \\
\text { terhadap } \\
\text { terhadap } \\
\text { kinerja guru } \\
\text { dalam } \\
\text { membuat } \\
\text { RPP? }\end{array}$ & $\begin{array}{l}\text { Analisis } \\
\text { regresi } \\
\text { sederhan } \\
\text { a }\end{array}$ \\
\hline
\end{tabular}

\section{Pembahasan}

Dari olahan hasil angket dan wawancara kepada responden dapat ditunjukkan data sebagai berikut:

\section{A. Seberapa baik keikutsertaan guru IPA MTs terhadap diklat guru IPA? \\ Dari angket yang dikirim oleh} responden (guru IPA MTs) dapat dibuat sebaran sebagai berikut:

Tabel 1. Sebaran Keikutsertaan Diklat Guru IPA MTs

\begin{tabular}{|c|c|c|c|c|c|c|}
\hline \multirow[t]{2}{*}{$\mathrm{NO}$} & \multirow[t]{2}{*}{ Pernyataan } & \multicolumn{5}{|c|}{ Skor } \\
\hline & & 4 & 3 & 2 & 1 & $\sum$ \\
\hline 1 & $\begin{array}{l}\text { Selama } \\
\text { mengikuti } \\
\text { diklat, } \\
\text { Bapak/Ibu } \\
\text { masuk } \\
\text { sebelum } \\
\text { Widyaiswara } \\
\text { /Dosen } \\
\text { memasuki }\end{array}$ & 10 & 8 & 1 & 2 & 21 \\
\hline
\end{tabular}




\begin{tabular}{|c|c|c|c|c|c|c|}
\hline & ruang kelas. & & & & & \\
\hline 2 & $\begin{array}{l}\text { Selama } \\
\text { mengikuti } \\
\text { diklat, } \\
\text { Bapak/Ibu } \\
\text { kadang- } \\
\text { kadang } \\
\text { terlambat } \\
\text { mengikuti } \\
\text { sesi/pelajara } \\
\text { n. }\end{array}$ & 4 & 8 & 5 & 4 & 21 \\
\hline 3 & $\begin{array}{l}\text { Selama } \\
\text { mengikuti } \\
\text { diklat, } \\
\text { Bapak/Ibu } \\
\text { memahami } \\
\text { dengan baik } \\
\text { setiap materi } \\
\text { yang } \\
\text { disampaikan } \\
\text {. }\end{array}$ & 12 & 6 & 2 & 1 & 21 \\
\hline 4 & $\begin{array}{l}\text { Selama } \\
\text { mengikuti } \\
\text { diklat, } \\
\text { Bapak/Ibu } \\
\text { aktif } \\
\text { bertanya } \\
\text { atau sekedar } \\
\text { memberi } \\
\text { respon. }\end{array}$ & 6 & 5 & 5 & 5 & 21 \\
\hline 5 & $\begin{array}{l}\text { Bapak/Ibu } \\
\text { tertarik atau } \\
\text { menaruh } \\
\text { minat pada } \\
\text { isi materi } \\
\text { diklat. }\end{array}$ & 9 & 7 & 3 & 2 & 21 \\
\hline 6 & $\begin{array}{l}\text { Materi yang } \\
\text { disampaikan } \\
\text { oleh } \\
\text { widyaiswara } \\
\text { adalah } \\
\text { materi yang } \\
\text { baru bagi } \\
\text { Bapak/Ibu } \\
\text { atau peserta } \\
\text { diklat dan } \\
\text { teraktual } \\
\text { saat ini } \\
\text { dihadapi } \\
\text { oleh } \\
\text { Bapak/Ibu } \\
\text { atau peserta }\end{array}$ & 7 & 8 & 4 & 2 & 21 \\
\hline
\end{tabular}

\begin{tabular}{|c|c|c|c|c|c|c|}
\hline & diklat. & & & & & \\
\hline 7 & $\begin{array}{l}\text { Bapak/Ibu } \\
\text { lebih tertarik } \\
\text { pada } \\
\text { penampilan } \\
\text { widyaiswara } \\
\text { /dosen } \\
\text { daripada } \\
\text { pada materi } \\
\text { yang } \\
\text { disampaikan }\end{array}$ & 6 & 5 & 5 & 5 & 21 \\
\hline 8 & $\begin{array}{l}\text { Pada saat } \\
\text { mengikuti } \\
\text { pelajaran } \\
\text { Bapak/Ibu } \\
\text { mudah } \\
\text { terganggu } \\
\text { oleh suara- } \\
\text { suara lain, } \\
\text { seperti } \\
\text { teman yang } \\
\text { lagi ngobrol. }\end{array}$ & 10 & 6 & 4 & 1 & 21 \\
\hline 9 & $\begin{array}{l}\text { Bapak/Ibu } \\
\text { tertarik pada } \\
\text { cara atau } \\
\text { metode } \\
\text { penyampaia } \\
\text { n yang } \\
\text { ditempuh } \\
\text { widyaiswara }\end{array}$ & 7 & 7 & 3 & 4 & 21 \\
\hline 10 & $\begin{array}{l}\text { Selama } \\
\text { mengikuti } \\
\text { diklat } \\
\text { Bapak/Ibu } \\
\text { pernah } \\
\text { merasa } \\
\text { bosan atau } \\
\text { jenuh. }\end{array}$ & 4 & 8 & 2 & 7 & 21 \\
\hline 11 & $\begin{array}{l}\text { Bila } \\
\text { Bapak/Ibu } \\
\text { tidak/kurang } \\
\text { mengerti apa } \\
\text { yang } \\
\text { dijelaskan } \\
\text { dosen/widya } \\
\text { iswara } \\
\text { Bapak/Ibu } \\
\text { bertanya } \\
\text { atau } \\
\text { berbisik- } \\
\text { bisik kepada } \\
\text { teman }\end{array}$ & 3 & 7 & 6 & 5 & 21 \\
\hline
\end{tabular}




\begin{tabular}{|c|c|c|c|c|c|c|}
\hline & sebangku & & & & & \\
\hline 12 & $\begin{array}{l}\text { Bapak/Ibu } \\
\text { lebih } \\
\text { mengerti isi } \\
\text { materi } \\
\text { setelah } \\
\text { mendapat } \\
\text { penjelasan } \\
\text { dari } \\
\text { widyaiswara }\end{array}$ & 10 & 7 & 3 & 1 & 21 \\
\hline 13 & $\begin{array}{l}\text { Bapak/Ibu } \\
\text { lebih mudah } \\
\text { mengerti isi } \\
\text { meteri } \\
\text { setelah } \\
\text { diberi } \\
\text { contoh- } \\
\text { contoh oleh } \\
\text { dosen/widya } \\
\text { iswara }\end{array}$ & 8 & 6 & 4 & 3 & 21 \\
\hline 14 & $\begin{array}{l}\text { Bapak/Ibu } \\
\text { lebih mudah } \\
\text { memahami } \\
\text { isi materi } \\
\text { setelah } \\
\text { diperagakan } \\
\text { oleh } \\
\text { widyaiswara }\end{array}$ & 9 & 5 & 6 & 1 & 21 \\
\hline 15 & $\begin{array}{l}\text { Bapak/Ibu } \\
\text { mengaitkan } \\
\text { apa yang } \\
\text { diperoleh di } \\
\text { tempat OL } \\
\text { (opservasi } \\
\text { lapangan) } \\
\text { dengan } \\
\text { kondisi di } \\
\text { madrasah } \\
\text { Bapak/Ibu. } \\
\end{array}$ & 8 & 3 & 9 & 1 & 21 \\
\hline 16 & $\begin{array}{l}\text { Bapak/Ibu } \\
\text { membuat } \\
\text { program } \\
\text { tahunan/prog } \\
\text { ran semester }\end{array}$ & 6 & 8 & 5 & 2 & 21 \\
\hline 17 & $\begin{array}{l}\text { Bapak/Ibu } \\
\text { memiliki } \\
\text { Rencana } \\
\text { Pelaksanaan }\end{array}$ & 8 & 8 & 4 & 1 & 21 \\
\hline
\end{tabular}

\begin{tabular}{|c|c|c|c|c|c|c|}
\hline & $\begin{array}{l}\text { Pembelajara } \\
\mathrm{n}(\mathrm{RPP})\end{array}$ & & & & & \\
\hline 18 & $\begin{array}{l}\text { Bapak/Ibu } \\
\text { ketika } \\
\text { mengikuti } \\
\text { diklat } \\
\text { menikmati } \\
\text { kerja } \\
\text { kelompok }\end{array}$ & 7 & 8 & 4 & 2 & 21 \\
\hline 19 & $\begin{array}{l}\text { Bapak/Ibu } \\
\text { ketika diklat } \\
\text { tampil } \\
\text { mempresent } \\
\text { asikan hasil } \\
\text { kerja }\end{array}$ & 6 & 8 & 4 & 3 & 21 \\
\hline 20 & $\begin{array}{l}\text { Bapak/Ibu } \\
\text { menikmati } \\
\text { kerja } \\
\text { individual } \\
\text { daripada } \\
\text { kerja } \\
\text { kelompok }\end{array}$ & 3 & 4 & 10 & 4 & 21 \\
\hline 21 & $\begin{array}{l}\text { Bapak/Ibu } \\
\text { menikmati } \\
\text { peragaan } \\
\text { dari } \\
\text { widyaiswara } \\
\text { /dosen }\end{array}$ & 8 & 6 & 4 & 3 & 21 \\
\hline 22 & $\begin{array}{l}\text { Bapak/Ibu } \\
\text { mengerjakan } \\
\text { tugas } \\
\text { mandiri } \\
\text { dengan baik } \\
\text { pada malam } \\
\text { hari setelah } \\
\text { siangnya } \\
\text { mendapat } \\
\text { materi }\end{array}$ & 4 & 6 & 5 & 6 & 21 \\
\hline 23 & $\begin{array}{l}\text { Menurut } \\
\text { Bapak/Ibu } \\
\text { materi diklat } \\
\text { berkaitan } \\
\text { erat dengan } \\
\text { tugas } \\
\text { Bapak/Ibu } \\
\text { sehari-hari }\end{array}$ & 8 & 6 & 4 & 3 & 21 \\
\hline
\end{tabular}

Penjelasan data sebagai berikut:

Keikutsertaan guru diklat : $(163 \times 4)+(150$ x 3$)+(102 \times 2)+(68 \times 1)=1374$

Oleh karena jumlah responden 21 orang dan banyaknya indicator angket 23 maka jika jika semua responden memberi 
skor 4 pada setiap pertanyaan maka akan diperoleh hasil keikutsertaan guru dalam diklat sebagai berikut:

$$
21 \times 23 \times 4=1932 \text {. }
$$

Jadi tingkat keikutsertan guru dalam diklat IPA MTs adalah 1374/1932 × $4=$ $0,71 \times 4=2,84$ ( mendekati baik ). Ini berarti guru aktif dan antusias dalam mengikuti kegiatan dalam kediklatan, materi yang disajikan oleh widyaiswara dirasa penting, guru telah mengimplimentasikan dan mengaplikasikan materi dari hasil Pendidikan dan Latihan (diklat) guru IPA Tingkat MTs dalam membuat Rencana Pelaksanaan Pembelajaran (RPP) tersebut sekembali di tempat tugas masing-masing dan guru telah mengadakan pengembangan - pengembangan dari hasil diklat.

Tingkat keikutsertaan guru dalam mengikuti Diklat Peningkatan guru IPA Tingkat MTs dalam Membuat Rencana Peleksanaan Pembelajaran (RPP) yang mendekati baik (belum baik) ini disebabkan antara lain: a) sebagian status peserta diklat (responden) masih pegawai swasta atau bukan karyawan Aparatur Sipil Negara (non ASN), sehingga kurangnya motivasi dan semangat dari peserta dalam mengikuti Pendidikan dan Latihan ini, dikarenakan mereka merasa tidak mempunyai suatu tanggung jawab yang besar untuk menjadi guru yang profesional.

Ini terlihat pada indikator nomor 10 dan 11 dimana responden atau peserta Pendidikan dan Latihan (Diklat) tersebut masih memberikan respon bosan dan kurang mengerti dengan materi-materi Diklat yang diberikan oleh widyaiswara (Nara Sumber). Sebagian peserta yang ikut dalam pelatihan tersebut sudah perna mengikuti Pendidikan dan Latihan (diklat) yang sama yang diselenggarakan oleh Balai Diklat Keagamaan Palembang sebagai Instansi yang legal dalam menyelenggarakan Diklat.

\section{B. Seberapa baik kualitas RPP yang dibuat oleh guru IPA MTs?}

Dari angket yang dikirim oleh responden (guru IPA MTs) dapat dibuat sebaran sebagai berikut:

Tabel 2. Sebaran Data Kinerja Guru dalam Membuat RPP

\begin{tabular}{|c|c|c|c|c|c|c|}
\hline \multirow[t]{2}{*}{ No } & \multirow[t]{2}{*}{ Pernyataan } & \multicolumn{5}{|c|}{ Skor } \\
\hline & & 4 & 3 & 2 & 1 & $\sum$ \\
\hline 1 & $\begin{array}{l}\text { Keilmiahan } \\
\text { silabus }\end{array}$ & 8 & 6 & 4 & 3 & 21 \\
\hline 2 & $\begin{array}{l}\text { Kerelevansian } \\
\text { silabus }\end{array}$ & 7 & 7 & 3 & 4 & 21 \\
\hline 3 & $\begin{array}{l}\text { Sistimatika } \\
\text { silabus }\end{array}$ & 8 & 6 & 4 & 3 & 21 \\
\hline 4 & $\begin{array}{l}\text { Konsistensi } \\
\text { silbus }\end{array}$ & 9 & 8 & 3 & 1 & 21 \\
\hline 5 & $\begin{array}{l}\text { Silabus sudah } \\
\text { memadai }\end{array}$ & 7 & 8 & 3 & 3 & 21 \\
\hline 6 & $\begin{array}{l}\text { Silabus sudah } \\
\text { aktual dan } \\
\text { kontektual }\end{array}$ & 7 & 7 & 3 & 4 & 21 \\
\hline 7 & $\begin{array}{l}\text { Fleksibilitas } \\
\text { silabus }\end{array}$ & 6 & 8 & 4 & 3 & 21 \\
\hline 8 & $\begin{array}{l}\text { Silabus sudah } \\
\text { menyeluruh }\end{array}$ & 7 & 6 & 4 & 4 & 21 \\
\hline 9 & $\begin{array}{l}\text { Perumusan } \\
\text { tujuan } \\
\text { pembelajaran }\end{array}$ & 6 & 6 & 8 & 1 & 21 \\
\hline 10 & $\begin{array}{l}\text { Pengembangan } \\
\text { dan } \\
\text { pengorganisasi } \\
\text { an materi } \\
\text { pembelajaran }\end{array}$ & 7 & 6 & 4 & 4 & 21 \\
\hline 11 & $\begin{array}{l}\text { Perencanaan } \\
\text { skenario } \\
\text { pembelajaran }\end{array}$ & 9 & 8 & 2 & 2 & 21 \\
\hline 12 & $\begin{array}{l}\text { Perancanan } \\
\text { pengelolaan } \\
\text { kelas }\end{array}$ & 10 & 8 & 3 & 0 & 21 \\
\hline
\end{tabular}




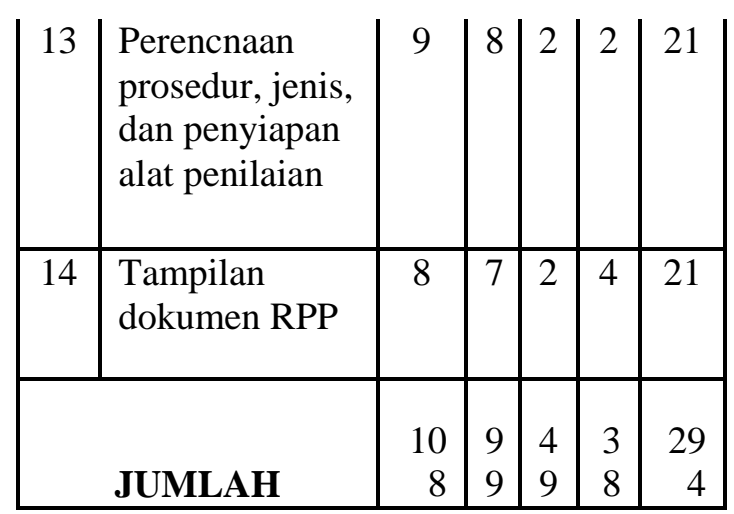

\section{Penjelasan data sebagai berikut:}

Motivasi dan kinerja guru dalam membuat silabus dan RPP: $(108 \times 4)+(99$ x 3$)+(49$ x 2$)+(38$ x 1$)=865$

Oleh karena jumlah responden sebanyak 21 orang dan banyaknya indikator angket 14, apabila semua responden memberi skor 4 pada setiap instrumen pertanyaan maka akan diperoleh hasil keikutsertaan guru dalam diklat sebagai berikut:

$$
21 \times 14 \times 4=1176 .
$$

Jadi tingkat kinerja guru dalam membuat silabus dan RPP adalah $865 / 1176 \times 4=0,73 \times 4=2,92$ berkategori baik . Berdasarkan Permendiknas Nomor 41 tahun 2007 silabus dan Rencana Pelaksanaan Pembelajaran (RPP) yang dibuat dan disusun oleh guru sudah relevan dan sesuai dengan prinsip-prinsip pembuatan silabus dan Rencana Pelaksanaan Pembelajaran (RPP) Walaupun sudah sesuai dan relevan dengan prinsip prinsip pembuatan silabus dan Rencana Pelaksanaan Pembelajaran (RPP) masih ada beberapa hambatan dan kendala di lapangan yang sering dialami Sebagian peserta pelatihan terutama dalam merumuskan dan menentukan tujuan pembelajaran, seperti terlihat pada tabel Tabel 2 indikator nomor 9 terdata:

$(6 \times 4+6 \times 3+8 \times 2 \times 1 / 21=59 / 21=2,8$,

\section{katagori mendekati baik).}

Hal ini disebabkan antara lain : a) sebagian peserta masih mengalami kesulitan dalam menentukan materi-materi essensial yang akan diajarkan sesuia dengan apa yang terdapat pada kompetensi dasar (KD) untuk seluruh mata pelajaran yang akan diberikan, b) sebagian peserta masih banyak berlatar belakang pendidikan bukan Pendidikan Ilmu Pengetahuan Alam (IPA). Mereka ada yang berlatar belakang pendidikan mata pelajaran lain seperti Pendidikan Matematika, Pendidikan Ilmu Pengetahuan Sosial dan Bahasa Indonesia. bahkan ada yang berlatar belakang pendidikan Olahraga dan Kesehatan.

\section{A. Apakah ada pengaruh diklat digunakan uji Regresi dengan langkah -langkah sebagai berikut: \\ 1) Pengujian Hipotesis}

Ha : Ada pengaruh yang signifikan antara keikutsertaan diklat Peningkatan Kompetensi guru IPA Tingkat MTs terhadap kinerja guru dalam membuat Rencana Pelaksanaan Pembelajaran.

Ho : Tidak ada pengaruh yang signifikan antara keikutsertaan diklat Peningkatan Kompetensi guru IPA terhadap kinerja guru dalam membuat Rencana Pelaksanaan Pembelajaran.

2) Uji Regresi

a) Menampilkan kelompok data diklat guru (variabel $\mathrm{x}$ ) dan kinerja guru dalam membuat rpp (variabel y)

Tabel 3. Kelompok Data Diklat Guru (variabel X) dan Kinerja Guru dalam Membuat RPP (variabel Y)

\begin{tabular}{|l|l|c|c|c|c|c|}
\hline No & Pernyataan & \multicolumn{5}{|c|}{ Skor } \\
\cline { 3 - 7 } 1 & $\begin{array}{l}\text { Keilmiahan } \\
\text { silabus }\end{array}$ & 8 & 6 & 4 & 3 & 21 \\
\hline 2 & $\begin{array}{l}\text { Kerelevansi } \\
\text { an silabus }\end{array}$ & 7 & 7 & 3 & 4 & 21 \\
\hline 3 & $\begin{array}{l}\text { Sistimatika } \\
\text { silabus }\end{array}$ & 8 & 6 & 4 & 3 & 21 \\
\hline 4 & $\begin{array}{l}\text { Konsistensi } \\
\text { silbus }\end{array}$ & 9 & 8 & 3 & 1 & 21 \\
\hline 5 & $\begin{array}{l}\text { Silabus } \\
\text { sudah } \\
\text { memadai }\end{array}$ & 7 & 8 & 3 & 3 & 21 \\
\hline 6 & $\begin{array}{l}\text { Silabus } \\
\text { sudah aktual } \\
\text { dan } \\
\text { kontektual }\end{array}$ & 7 & 7 & 3 & 4 & 21 \\
\hline 7 & $\begin{array}{l}\text { Fleksibilitas } \\
\text { silabus }\end{array}$ & 6 & 8 & 4 & 3 & 21 \\
\hline
\end{tabular}




\begin{tabular}{|l|l|c|c|c|c|c|}
\hline 8 & $\begin{array}{l}\text { Silabus } \\
\text { sudah } \\
\text { menyeluruh }\end{array}$ & 7 & 6 & 4 & 4 & 21 \\
\hline 9 & $\begin{array}{l}\text { Perumusan } \\
\text { tujuan } \\
\text { pembelajara } \\
\text { n }\end{array}$ & 6 & 6 & 8 & 1 & 21 \\
\hline 10 & $\begin{array}{l}\text { Pengemban } \\
\text { gan dan } \\
\text { pengorganis } \\
\text { asian materi } \\
\text { pembelajara } \\
\text { n }\end{array}$ & 7 & 6 & 4 & 4 & 21 \\
\hline 11 & $\begin{array}{l}\text { Perencanaan } \\
\text { skenario } \\
\text { pembelajara } \\
\text { n }\end{array}$ & 9 & 8 & 2 & 2 & 21 \\
12 & $\begin{array}{l}\text { Perancanan } \\
\text { pengelolaan } \\
\text { kelas }\end{array}$ & 10 & 8 & 3 & 0 & 21 \\
\hline 13 & $\begin{array}{l}\text { Perencnaan } \\
\text { prosedur, } \\
\text { jenis, dan } \\
\text { penyiapan } \\
\text { alat } \\
\text { penilaian }\end{array}$ & 9 & 8 & 2 & 2 & 21 \\
\hline 14 & $\begin{array}{l}\text { Tampilan } \\
\text { dokumen } \\
\text { RPP }\end{array}$ & 8 & 7 & 2 & 4 & 21 \\
\hline Jumlah & 108 & 99 & 49 & 38 & 294 \\
\hline
\end{tabular}

\section{Ringkasan dalam table Anava adalah}

1. Menghitung jumlah kuadrat regresi $\left(\mathrm{JK}_{\text {regresi a) }}\right)$.

$$
J K_{\text {reg }(a)}=\frac{\left(\sum Y\right)^{2}}{N}=\frac{(864)^{2}}{21}=\frac{746,496}{21}=35,547
$$

2. Menghitung jumlah kuadrat regresi b/a $\left(\mathrm{JK}_{\text {reg b a a }}\right)$

$$
J K_{r e g(b / a)}=b \cdot\left(\sum X Y-\frac{\sum X \cdot \sum Y}{n}\right)
$$

$b=\frac{N \cdot\left(\sum X . Y\right)-\sum X \sum Y}{N \cdot \sum X^{2}-\left(\sum X\right)^{2}}=\frac{21(56885)-(1374) \cdot(865)}{7374}=0,82$

maka:

$$
J K_{r e g(b / a)}=b \cdot\left(\sum X Y-\frac{\sum X \cdot \sum Y}{n}\right)
$$

$$
\begin{aligned}
& =0,82\left(56885-\frac{(1374) \cdot(864)}{21}\right) \\
& =0,82(357,72) \\
& =293,33
\end{aligned}
$$

3. Menghitung jumlah kuadrat residu $\left(\mathrm{JK}_{\mathrm{res}}\right)$

$$
\begin{aligned}
J K_{\text {res }} & =\sum Y^{2}-J K_{\operatorname{Re} g(b / a)}-J K_{\operatorname{Re} g(a)} \\
& =36066-35547-293,33 \\
& =225,67
\end{aligned}
$$

4. Menghitung rata-rata jumlah kuadrat regresi a $\left(\mathrm{RJK}_{\text {reg (a) }}\right)$

$R J K_{\operatorname{Re} g(a)}=J K_{\operatorname{Re} g(a)}=35.547$

5. Menghitung rata-rata jumlah kuadrat regresi b/a $\left(\mathrm{RJK}_{\text {reg (a) }}\right)$

$R J K_{\operatorname{Re} g(a)}=J K_{\operatorname{Re} g(b / a)}=393,33$

6. Menghitung rata-rata jumlah kuadrat residu $\left(\mathrm{RJK}_{\mathrm{res}}\right)$

$R J K_{\mathrm{Res}}=\frac{J k_{\mathrm{Res}}}{n-2}=\frac{225,67}{21-2}=11,87$

7. Menghitung nilai uji $\mathrm{F}$ :

$F=\frac{R J k_{\operatorname{Re} g(b / a)}}{R J K_{\text {Res }}}=\frac{293,33}{11,87}=24,71$

8. Menentukan nilai titik dan daerah kritis. Nilai tabel F pada $\alpha=5 \%$ adalah $\mathrm{F}_{(95 \%)(1)(19)}=4,38$

9. Kesimpulan: karena nilai uji $\mathrm{F}>$ nilai tabel $\mathrm{F}$, maka $\mathrm{H}_{0}$ ditolak. Artinya regresi tersebut di atas berarti.

10. Berarti pula ada pengaruh signifikan antara keikutsertaan diklat guru IPA MTs terhadap kinerja guru dalam membuat silabus dan RPP. 


\section{PENUTUP}

\begin{tabular}{|l|c|c|c|c|}
\hline $\begin{array}{l}\text { Sumber } \\
\text { Varians }\end{array}$ & $\mathrm{dk}$ & $\mathrm{JK}$ & $\mathrm{KT}$ & $\mathrm{F}$ \\
\hline \hline Total & 21 & 36066 & - & - \\
\hline $\begin{array}{l}\text { Koefisi } \\
\text { en (a) }\end{array}$ & 1 & $\begin{array}{c}35,54 \\
7\end{array}$ & $\begin{array}{c}35,54 \\
7\end{array}$ & \multirow{2}{*}{} \\
\cline { 1 - 4 } $\begin{array}{l}\text { Regresi } \\
\text { b/a) }\end{array}$ & 1 & $\begin{array}{c}293,3 \\
3\end{array}$ & $\begin{array}{c}293,3 \\
3\end{array}$ & \multirow{2}{*}{24,71} \\
\cline { 1 - 3 } Sisa & 19 & $\begin{array}{c}225,6 \\
7\end{array}$ & $\begin{array}{c}11,87 \\
\end{array}$ & \\
\hline
\end{tabular}

A. Simpulan

1. Keikutsertaan guru mata pelajaran IPA MTs dalam diklat guru IPA dapat dikatakan berkategori baik.

2. Motivasi dan Kinerja guru dalam membuat Rencana pelaksanaan Pembelajaran (RPP) baik.

3. Ada pengaruh yang signifikan antara keikutsertaan diklat guru mata pelajaran IPA tingkat MTs terhadap kinerja guru dalam membuat Rencana Pelaksanaan Pembelajaran. Ini berarti keikutsertaan guru dalam setiap materi kediklatan meningkatkan kualitas kinerjanya dalam membuat Rencana Pelaksanaan Pembelajaran (RPP).

\section{B. Rekomendasi}

1. Sistem pemanggilan peserta diklat perlu diperbaikai supaya peserta yang ikut diklat:

a) Berlatarbelakang pendidikan yang sama atau serumpun.

b) pegawai negeri semua atau swasta semua.

2. Metode penyampaian materi widyaiswara perlu dibuat yang bervariasi supaya peserta diklat lebih termotivasi untuk mengikuti kediklatan dengan baik 


\section{DAFTAR PUSTAKA}

Barinto. (2012). Hubungan kompetensi guru dan supervisi akademik dengan kinerja guru SMP Negeri Kecamatan Percut Sei Tuan. Jurnal Tabularasa, 9 (2), 187-200.

Black A.J dan Champion J.D (2001), Metode dan Masalah Penelitian Sosial, Refika, Bandung

Danim, Sudarwan. (2002). Inovasi Pendidikan dalam upaya Peningkatan Profesionalisme Tenaga Kependidikan. Bandung: Pustaka Setia.

Darsana W., 2012. Hubungan stimulasi kecerdasan multipel dengan perkembangan personalsosial anak usia pra sekolah.

DPR RI, 2005, Undang-Undang Guru dan Dosen, Jakarta

Hasibuan, S.P.Malayu. 2008. Manajemen Sumber Daya Manusia. Jakarta

Kemendiknas. (2007). Peraturan Menteri Pendidikan Nasional Nomor 16 Tahun 2007 tentang Standar Kualifikasi Akademik dan Kompetensi Guru. Jakarta: Kemndiknas.

Mason D, Lind A, \& Marchal G (1988) Satistics An Intoduction, Harcourt Brace Jovanovich, New York Amerika

Peratuaran Pemerntah RI no 19 th 2005 . Standart Nasional pendidikan, Jakarta

Permendiknas RI Nomor 41 Tahun 2007. Standar Proses, Jakarta

Permendiknas RI no 22 th 2006 . standart isi, Jakarta

Pidarta , M, (2000) Landasan Kependidikan, Rineka Cipta, Jakarta

Purwanto, N. (2000). Ilmu pendidikan teoritis dan praktis Bandung: PT Remaja Rosdakarya.

Rohani,Ahmad, H.M. dan Ahmadi Abu, H (1990), Pengelolaan Pengajaran: Jakarta Rineka Cipta.

Subana, dkk. 2005. Statistik Pendidikan. Bandung : Pustaka Setia.

Sudjana, N., 1992, Metoda Statistika, Bandung : Tarsito.

Supriyono. 2007. Evaluasi Program untuk Pendidikan dan Pelatihan. Surabaya:BPPLSP Regional IV.

Syah M, (2001) Psikologi Belajar, Logos Wacana Ilmu, Jakarta.

Wiersma, W., 1995, Research Methods in Education (6th ed), Boston : Allyn and Bacon. 